\title{
SISTEM HUKUM KELUARGA ISLAM DI INDONESIA
}

\author{
Holan Riadi \\ IAI Al Khoziny Sidoarjo, Indonesia \\ holanriadi@gmail.com
}

\begin{abstract}
Abstrak: Hukum keluarga secara garis besar merupakan hukum yang bersumber pada pertalian kekeluargaan. Pertalian kekeluargaan ini dapat terjadi karena pertalian darah, ataupun terjadi karena adanya sebuah perkawinan. Hubungan keluarga sangat penting karena ada sangkut pautnya dengan hubungan anak dan orang tua, hukum waris, perwalian dan pengampuan. Pada dasarnya sumber hukum keluarga dapat dibedakan menjadi dua macam, yaitu sumber hukum tertulis dan tidak tertulis. Sumber hukum keluarga tertulis adalah sumber hukum yang berasal dari berbagai peraturan perundangundangan, yurisprudensi, dan traktat. Sedangkan sumber hukum tak tertulis adalah sumber hukum yang tumbuh dan berkembang dalam kehidupan masyarakat. Dengan demikian, dalam Hukum Keluarga Islam di Indonesia memberikan kepastian hukum yang jelas bagi para keluarga muslim. Tujuannya untuk dijadikan pedoman hukum bagi setiap keluarga di kedua negara ini.
\end{abstract}

Kata Kunci: Hukum Keluarga, Legislasi, dan Perkawinan 


\section{PENDAHULUAN}

Hukum keluarga Islam dirasa sangat penting kehadirannya di tengah-tengah masyarakat muslim karena permasalahan tentang keluarga menyangkut tentang perkawinan, kewarisan dan lain sebagainya yang tidak bisa disamakan dengan yang beragama non muslim, sehingga masyarakat menginginkan adanya hukum keluarga Islam yang berlaku khusus, apalagi dengan perkembangan zaman yang semakin berkembang pula sehingga dibutuhkan metodemetode untuk pembaruan hukum. Lahirnya Undang-Undang No. 1 Tahun 1974 tentang perkawinan dan KHI (Kompilasi Hukum Islam) adalah jawaban dari keresahan, ketidakpastian dan tuntutan masyarakat muslim untuk menjadi pedoman, dan rujukan dalam mengatasi permasalahan seputar hukum keluarga. ${ }^{1}$

Adapun yang pertama ialah undang-undang yang berlaku di negara-negara muslim khususnya mengenai hukum keluarga. Sedangkan yang kedua adalah kompilasi hukum Islam yang sebenarnya merupakan inovasi Indonesia. Kompilasi bukan kodifikasi, tetapi juga bukan kitab fiqh. Sesuai dengan UndangUndang No. 1 tahun 1974 tentang Perkawinan dan Undang-Undang No.7 tahun 1989 tentang Peradilan Agama, umat Islam Indonesia telah memiliki peraturan perundangundangan yang memadai untuk mengatur masalah-masalah keluarga, perkawinan, perceraian dan warisan. ${ }^{2}$

Ulama tradisional Indonesia masih ada yang belum sepenuhnya memahami atau menyetujui berbagai aturan dalam kedua undang-undang tersebut karena dianggap tidak selamanya sesuai dengan apa yang termuat dalam kitab-kitab fiqh. Akan tetapi sebagian ulama lain merasa bangga dengan lahirnya kedua undang-undang itu karena dianggap sebagai kemajuan besar dalam perkembangan pemikiran hukum Islam di Indonesia. Apalagi dengan disepakatinya hasil Kompilasi Hukum Islam oleh para ulama Indonesia pada tahun 1988 yang kemudian diikuti oleh Instruksi Presiden No. 1 tanggal 10 Juni 1991 untuk menyebarluaskan dan sedapat mungkin menerapkan isi kompilasi tersebut, hal ini telah menandai lembaran baru dalam perkembangan pemikiran Islam di Indonesia khususnya dalam bidang hukum keluarga. ${ }^{3}$

\footnotetext{
1 Saeed, Abdullah. Pemikiran Islam: Sebuah Pengantar. Yogyakarta: Baitul Hikmah. 2014.

${ }^{2}$ M. Mudzhar, "Dampak Gender Terhadap Perkembangan Hukum Islam”, Jurnal Studi Islam, 1, (1999), h. 172.

3 John Donohue, Islam dan Pembaharuan Ensiklopedi Masalah-Masalah. Jakarta: Rajawali Press, 1995), h. 365
} 
Dalam hukum keluarga di Indonesia perkawinan mendapatkan perhatian tersendiri. Secara substantif, hukum perkawinan Indonesia merupakan penjabaran hukum perkawinan dalam Islam. Sebagai negara dengan penduduk muslim terbesar di dunia, wajar jika bangsa Indonesia menjadikan Islam sebagai rujukan perundang-undangan, termasuk dalam perkawinan. Hukum keluarga mempunyai posisi yang penting dalam Islam. Hukum keluarga dianggap sebagai inti syari'ah. Hal ini berkaitan dengan asumsi umat Islam yang memandang hukum keluarga sebagai pintu gerbang untuk masuk lebih jauh ke dalam agama Islam.

\section{METODE}

Penelitian ini menggunakan pendekatan penelitian kualitatif dengan jenis penelitian deskriptif analitik. Adapun Teknik pengumpulan data yaitu studi literature. Penelitian kualitatif merupakan jenis penelitian yang mengumpulkan data berupa kata-kata yang digunakan sebagai sumber data dan bukan menggunakan angka sebagai objek penelitiannya. Penelitian kualitatif memiliki tujuan untuk memahami fenomena yang terjadi didalam kehidupan oleh subjek penelitian di lapangan. ${ }^{4}$ Adapun jenis penelitian ini menggunakan deskriptif analitik dimana peneliti tidak hanya menjelaskan fenomena tertentu, tetapi peneliti turut serta melakukan analisis terhadap fenomena yang terjadi sesuai dengan yang terjadi di lapangan. Seperti yang telah dijelaskan diatas, penelitian ini menggunakan Teknik pengumpulan data berupa studi literature untuk mengumpulkan data-data sebagi sumber utama penelitian ini sehingga penelitian ini validasi yang tinggi sesuai yang terjadi di lapangan. Kemudian, setelah peneliti mendapatkan literature yang sesuai dengan penelitian ini. Kajian pengembangan karakter kepribadian anak usia dasar akan dilakukan dengan melakukan analisis data sesuai dengan literature yang ada dalam penelitian ini

\section{DEFINISI HUKUM KELUARGA ISLAM}

Hukum keluarga dalam pengertian sempit yakni hukum perkawinan dan perceraian, terdapat dalam berbagai kitab fiqhi di suatu negara. Pada umumnya kitab-kitab itu adalah hasil ijtihad pada mujâhid dari berbagai tingkatan untuk memenuhi kebutuhan hukum masyarakat muslim pada masanya. Hukum keluarga yang demikian dapat ditelusuri dalam kitab-kitab fikhi berbagai mazhab, seperti empat mazhab dalam sunni (Hanafi, Maliki, Syafi'i dan Hambali) dan tiga pada syiah (Itsna Asyari, Ismaili dan Zaidi).

\footnotetext{
${ }^{4}$ Moleong, Lexy J. Metodologi Penelitian Kualitatif. (Bandung: PT Rosdakarya, 2018), 84.
} 
Meskipun hasil penalaran para fuqaha di masa lampau telah memenuhi kebutuhan masyarakat muslim di masa itu, namun dalam konteks sekarang dianggap belum tentu sesuai. Disamping itu, isinya pun berbeda satu dengan lain karena tingkat penalarnya, meskipun mereka berada dalam satu mazhab yang sama. Adanya ketidakpuasan terhadap isi yang dikandungnya akibat perbedaan pendapat, menyebabkan masyarakat muslim yang belum paham justru mengikuti hukum adat yang turun temurun, bakan sistem hukum Kristen (barat) yang disusun secara sistematis dan jelas dalam satu kitab atau peraturan perundangundangan. $^{5}$

Hukum keluarga secara garis besar dapat dimaknai hukum mengatur tentang pertalian kekeluargaan. Pertalian kekeluargaan ini dapat terjadi karena pertalian darah, ataupun terjadi karena adanya sebuah perkawinan. Hubungan keluarga ini sangat penting sebab terkait dengan hubungan orang tua dan anak, hukum waris, perwalian, serta pengampuan. Hukum keluarga diartikan sebagai keseluruhan peraturan yang mengatur tentang hubungan kekeluargaan. Maksud kekeluargaan disini terdapat dua macam, yaitu pertama di tinjau dari hubungan darah dan kedua ditinjau dari hubungan perkawinan. Kekeluargaan ditinjau dari hubungan darah atau bisa disebut dengan kekeluargaan sedarah ialah pertalian keluarga yang terdapat antara beberapa orang yang mempunyai leluhur yang sama. Kekeluargaan karena perkawinan ialah pertalian keluarga yang terjadi karena sebab perkawinan antara seseorang dengan keluarga yang tidak sedarah dari istri (suaminya).

\section{KAJIAN HUKUM KELUARGA ISLAM}

Hukum keluarga Islam adalah alQuran dan al-Hadits. Kedua sumber tersebut kemudian digali yang hasilnya dapat berupa fiqh, fatwa dan bahkan peraturan perundangundangan (qânun). Tidak diragukan lagi bahwa banyak fiqh yang ditulis para ulama terkait dengan hukum keluarga Islam. Fiqh yang berkaitan dengan perkawinan dengan segala akibat hukumnya banyak terkondifikasi dalam fiqh munâkahat. Sedangkan fiqh yang terkait dengan pewarisan terkondifikasi dalam fiqh mawarits. Meskipun tidak berlaku secara yuridis formal, kedua produk hukum tersebut dapat dikategorikan sebagai hukum yang tertulis. Karena itu agar berlaku secara formal, produk hukum Islam (fiqh maupun fatwa) harus diadopsi menjadi peraturan perundang-undangan. 5 Muhammad Daud Ali, Hukum Islam dan Peradilan Agama. (Jakarta: P.T. Raja
Grafindo, 1997), h. 90-91 
Dalam pembaharuan hukum Islam, Indonesia cendrung menempuh jalan kompromi antara syariah dan hukum sekuler. Hukum keluarga di Indonesia dalam upaya perumusannya selain mengacu pada kitab-kitab fikih klasik, fikih modern, himpunan fatwa, keputusan pengadilan (yurisprudensi), juga ditempuh wawancara kepada seluruh ulama Indonesia. Pengambilan terhadap hukum barat sekuler memang tidak secara langsung dapat dibuktikan, tetapi karena di Indonesia berjalan cukup lama hukum perdata (Burgelijk Wetbook) yang diterjemahkan menjadi kitab undang-undang hukum perdata, hukum acara perdata (reglemen Indonesia yang diperbarui) warisan Belanda, dan hukum-hukum lain, berdasarkan asas konkordansi, adanya pengaruh hukum Barat yang tidak bisa dinaifkan begitu saja. Seperti halnya bidang pencatatan dalam perkawinan, kewarisan, perwakafan, wasiat dan sebagainya. Upaya akomodasi ataupun rekonsiliasi hukum keluarga Islam agar sesuai dengan perkembangan zaman demi menciptakan ketertiban masyarakat menjadi salah satu bukti dari keunikan tersebut.

\section{AZAZ HUKUM KELUARGA ISLAM}

Berdasarkan hasil analisis terhadap KUH Perdata dan UndangUndang No. 1 Tahun 1974, dirumuskan beberapa azas dalam hukum keluarga, yaitu: ${ }^{6}$

Pertama: Azas monogami, azas ini mengandung makna bahwa seorang pria hanya boleh mempunyai seorang istri, dan seorang istri hanya boleh mempunyai seorang suami;

Kedua: Azas konsensual, yakni azas yang mengandung makna bahwa perkawinan dapat dikatakan sah apabila terdapat persetujuan atau konsensus antara calon suami-istri yang akan melangsungkan perkawinan;

Ketiga: Azas persatuan bulat, yakni suatu azas dimana antara suami-istri terjadi persatuan harta benda yang dimilikinya (Pasal 119 KUH Perdata);

Keempat: Azas proporsional,yaitu suatu azas dimana hak dan kedudukan istri adalah seimbang dengan hak dan kewajiban suami dalam kehidupan rumah tangga dan di dalam pergaulan masyarakat (Pasal 31 Undang-Undang No.1 Tahun 1974 tentang perkawinan);

\footnotetext{
${ }^{6}$ Muttaqien, Dadan. Peradilan Agama dan Kompilasi Hukum Islam dalam Tata Hukum Indonesia.Yogyakarta : UII Press. 1999.
} 
Kelima: Azas tak dapat dibagibagi, yaitu suatu azas yang menegaskan bahwa dalam tiap perwalian hanya terdapat seorang wali.

\section{PEMBAHASAN}

\section{AWAL MULA HUKUM KELUARGA ISLAM}

hukum keluarga Islam untuk pertama kalinya dilakukan di Turki, diikuti Lebanon dan Mesir. Negara Brunei, Malaysia dan Indonesia juga masuk kategori ini. Turki mempunyai peran penting dalam sejarah hukum Islam, terutama di asia barat. Hukum perdata Turki pada awalnya didasarkan pada mazhab Hanafi, namun kemudian juga menampung mazhab-mazhab lain, seperti dalam Majallât al-ahkâm al-Âdliyah yang telah dipersiapkan sejak tahun 1876, namun di dalamnya tidak terdapat aturan tentang hukum keluarga. Aturan hukum yang berkaitan dengan perkawinan dan perceraian mulai dirintis tahun 1915. Materi perubahan pada tahun tersebut adalah kewenangan (hak) untuk menuntut cerai yang menurut mazhab Hanafi hanya menjadi otoritas suami. Bahkan para isteri yang merasa terikat oleh mazhab Hanafi tersebut yang justru pertama kali mendesak pemerintah Turki untuk melakukan pembaruan hukum keluarga.

Pada tahun 1912 Pemerintah Turki mengadopsi hukum perdata Swiss (The civil code of Switzerland, 1912) tentunya sudah disesuaikan dengan kondisi Turki dan diundangkan dalam hukum perdata Turki tahun 1926 (The Turkish civil code of 1926). Perbedaanya cukup signifikan bahwa beberapa ketentuan dalam hukum perdata Turki tahun 1926 ini sangat menyimpang dari hukum Islam tradisonal (fiqh konfensional), seperti ketentuan waris dan wasiat yang mengacu pada hukum perdata Swiss tahun 1912. Materi yang menonjol dalam hukum perdata Turki tahun 1926 adalah ketentuanketentuan tentang pertunangan (terutama masalah taklik talak), batas usia minimal untuk kawin, larangan menikah, poligami, pencatatan perkawinan, pembatalan perkawinan, perceraian, dan lain-lain. Menurut hukum perdata Turki tahun 1926, seorang suami atau isteri yang hendak bercerai diperbolehkan melakukan pisah ranjang. Jika setelah pisah ranjang dijalani pada waktu tertentu tidak ada perbaikan kondisi rumah tangga, maka masing-masing pihak mempunyai hak untuk mengajukan cerai di pengadilan.

Hukum tentang hak-hak keluarga (The Ottoman Law of Family Rights/Qanûn al-huqûq al-Â'ilah) yang dirintis sejak tahun 1915 kemudian diundangkan pada tahun 1917 adalah hukum keluarga yang diundangkan pertama kali di dunia Islam. Hukum tentang hak-hak 
keluarga tahun 1917 yang dikeluarkan oleh Pemerintahan Turki Usmani mengatur tentang hukum perorangan dan hukum keluarga (tidak termasuk waris, wasiat dan hibah). Undang-undang ini bersumber pada berbagai mazhab Sunni Hukum tentang hak-hak keluarga tahun 1917 dalam bagian tertentu berlaku bagi golongan minoritas Yahudi dan Nasrani, karena undang-undang tersebut dimaksudkan untuk menyatukan yurisdiksi hukum pada pengadilan-pengadilan nasional.

Dalam beberapa hal ketentuan dalam hukum perdata Turki tahun 1926 sangat menyimpang dari hukum Islam tradisonal, seperti ketentuan waris dan wasiat yang mengacu pada hukum perdata Swiss tahun $1912{ }^{7}$ Metode pembaruan hukum Islam yang digunakan di Turki pada tahap awal menggunakan metode takhayyur. Hal ini dapat dilihat pada kodifikasi hukum majalla-ât al-ahkâm al-adhiya tahun 1876 dengan memilih salah satu dari sekian pendapat mazhab fiqh yang ada.

\section{PERKEMBANGAN HUKUM KELUARGA ISLAM}

Secara historis, hukum keluarga Islam mencuat kepermukaan bermula dari diakuinya peradilan agama (PA) secara resmi sebagai salah satu pelaksana "judicial power" dalam negara hukum melalui Pasal 10 UndangUndang No. 14 Tahun 1970. Lebih lanjut, kedudukan, kewenangan atau yurisdiksi dan organisatorisnya telah diatur dan dijabarkan dalam Undang-Undang No. 7 Tahun 1989, Undang-Undang No. 3 Tahun 2006, yang mempunyai kewenangan mengadili perkara tertentu: (1) perkawinan, (2) waris, (3) wasiat, (4) hibah, (5) wakaf, (6) infaq, (7) shadaqah, (8) zakat dan (9) ekonomi syariee ah, bagi penduduk yang beragama Islam.

Kenyataan bahwa keberadaan pengadilan agama belum disertai dengan perangkat atau sarana hukum positif yang menyeluruh, serta berlaku secara unifikasi sebagai rujukan. Meskipun hukum materiil yang menjadi yurisdiksi pegadilan agama sudah dikodifikasi dalam UndangUndang No. 1 Tahun 1974 dan Peraturan Pemerintah No. 9 Tahun 1975, namun pada dasarnya hal-hal yang diatur didalamnya baru merupakan pokok-pokok. Akibatnya, para hakim yang seharusnya mengacu pada undang-undang, kemudian kembali merujuk kepada doktrin ilmu fiqh. Karena itu adanya perbedaan putusan hukum antar PA tentang persoalan yang sama adalah suatu hal yang dapat dimaklumi,

\footnotetext{
7 Mudzhar, M. Dampak Gender Terhadap Perkembangan Hukum Islam. Jurnal Studi Islam. Volume ke-1 Nomor 1: 1999.
} 
sebagaimana ungkapan different judge different sentence. ${ }^{8}$ Dari realitas di atas, pemerintah kemudian berinisiatif melengkapi pengadilan agama dengan prasarana hukum yang unifikatif lewat jalan pintas berupa kompilasi hukum Islam (KHI).

Terkait dengan teori diatas, hukum keluarga Islam yang temuat dalam berbagai aturan hukum, bila ditelaah secara mendalam, memang masih mengandung banyak kelemahan sebagai konsekuensi logis dari dinamika kehidupan. Lebih-lebih bila dihadapkan dengan kebutuhan dan kompleksitas problematika masyarakat saat ini, harus dilakukan upaya mengaktualisasikannya atau pembaharuan. Seperti, menguatnya arus yang menghendaki adanya kesetaraan laki-laki dan perempuan atau menghapus hukum-hukum yang bias gender yang cenderung menjadikan perempuan dalam posisi subordinat, serta adanya perbenturan beberapa pasal dengan struktur dan pola budaya masyarakat.

Tujuan lain yang dimiliki negara-negara Islam dalam memperbaharui hukum keluarga adalah unifikasi hukum. Usaha unifikasi hukum ini dilakukan karena masyarakatnya menganut bermacam-macam mazhab atau bahkan agama yang berbeda-beda. Di Tunisia misalnya, upaya unifikasi hukum perkawinan ditujukan untuk semua warga negara tanpa memandang perbedaan agama. Selain tujuantujuan tersebut, ada lagi tujuan lain dari upaya pembaharuan hukum keluarga yaitu untuk merespon tuntutan zaman. Dimana tuntutan zaman dan dinamika perkembangan masyarakat tersebut adalah akibat dari pengaruh global yang mempengaruhi hampir seluruh aspek kehidupan manusia.'

Dalam reformasi hukum keluarga tersebut, umumnya upaya terfokus pada masalah status personal, yang masih diatur oleh hukum Islam yang telah mapan di beberapa negara muslim. Untuk mengurangi keberatan kaum konservatif, pembaharuan ini sering dilakukan secara tak langsung melalui jalur prosedural. Sebagai contoh, hukum baru yang menuntut persyaratan bahwa pernikahan harus dicatat agar sah secara hukum dan bahwa pasangan harus sudah mencapai usia minimum tertentu, adalah upaya untuk menghalangi pernikahan dini dan perkawinan paksa.

\section{HUKUM KELUARGA ISLAM DI INDONESIA}

8 Donohue, John. Islam dan Pembaharuan Ensiklopedi Masalah-Masalah. Jakarta: Rajawali Press. 1995.

${ }_{9}^{9}$ Bisri, Cik Hasan. Kompilasi Hukum Islam dan Peradilan Agama dalam Sistem Hukum Nasional. Jakarta: Logos. 1999. 
Di Indonesia, hukum keluarga ini tercantum dalam UndangUndang No. 1 tahun 1974 tentang pekawinan, Peraturan Pemerintah No. 9 Tahun 1975 tentang pelaksanaan UU No. 1 Tahun 1974 tentang perkawinan dan Kompilasi Hukum Islam (KHI). Dalam UU tersebut, urusan tentang pernikahan, perceraian, perwakinan bertingkat, dan segala hal yang berkaitan dengan keluarga tercantum di dalamnya. hal ini disempurnakan dengan KHI yang memiliki tiga bab buku yang masingmasing memiliki bahasan yang berbeda. Sejarah pembentukan UU No. 1 Tahun 1974, PP. No. 9 Tahun 1975 dan KHI menunjukkan bahwa sumber utama yang mendominasi ketiga hukum keluarga tersebut adalah hukum Islam, hal ini bisa dilihat dari Pasal-Pasal yang ada didalamnya dan sejarah proses pembahasannya.

Undang-Undang Nomor 1 Tahun 1974 tentang perkawinan (UUP), yang terdiri dari 14 bab dan 67 Pasal, Peraturan Pemerintah (PP) Nomor 9 Tahun 1975 tentang pelaksanaan UU No. 1 Tahun 1974 tentang perkawinan, dan Instruksi Presiden RI Nomor 1 Tahun 1991 tentang Kompilasi Hukum Islam (KHI) yang terdiri dari Buku I tentang Hukum Perkawinan, Buku II tentang Hukum Kewarisan dan Buku III tentang Hukum Perwakafan. Ketiga peraturan perundang-undangan tersebut merupakan sumber hukum materiil yang menjadi rujukan utama hukum keluarga di lingkungan Peradilan Agama sebagai pengadilan yang salah satu kewenangannya menangani masalah-masalah hukum keluarga bagi orang yang beragama Islam.

Dalam UUP di antaranya adalah Pasal 2 tentang pencatatan nikah; Pasal 3, 4 dan 5 tentang poligami; Pasal 7 tentang usia pernikahan; Pasal 11 tentang masa tunggu bagi istri yang putus perkawinannya (iddah); Pasal 31 tentang hak dan kedudukan suami istri; dan Pasal 34 tentang kewajiban suami istri.

Sementara dalam KHI adalah dalam Buku I diantaranya Pasal 14 tentang pencatatan nikah; Pasal 25 tentang kesaksian perempuan dalam perkawinan; Pasal 15 tentang batas minimal usia perkawinan; Pasal 79 tentang kedudukan suami isteri; Pasal 80 tentang pencarian nafkah; Pasal 55-59 tentang poligami; Pasal 153 tentang Iddah; Pasal 84 tentang nusyuz (membangkang dari kewajiban); dan Pasal 163 tentang hak rujuk. Dalam Buku II diantaranya adalah Pasal 186 tentang anak diluar perkawinan, dan Pasal 176 tentang pembagian waris bagi anak laki-laki dan perempuan.

Ketentuan-ketentuan tentang hukum keluarga yang secara khusus mengatur orang muslim tercantum dalam Kompilasi Hukum Islam 
(KHI) pada Buku I hukum perkawinan. Buku I KHI berisi tentang seluk beluk perkawinan, sehingga memiliki Pasal-Pasal yang banyak. Secara keseluruhan berisi 19 Bab dan 170 Pasal. Lebih rincinya adalah sebagai berikut:

Satu: Pada Bab I berisi tentang ketentuan umum dan terdiri 1 Pasal. Pada bab ini dijelaskan tentang definisi-definisi operasional, seperti pengertian peminangan, akad nikah, wali, taklik talak, dan yang berhubungan dengan perkawinan.

Dua: Bab II tentang dasar-dasar perkawinan dan berisi 10 Pasal. Pada bab ini, dijelaskan dasar-dasar perkawinan, seperti perkawinan menurut Islam, tujuan perkawinan, perkawinan yang sah, dan lain-lain yang berkaitan dengan dasar perkawinan. Menurut Pasal 4, perkawinan Sah apabila dilakukan menurut hukum Islam sesuai dengan Pasal 2 ayat (1) Undang-undang No 1 tahun 1974 tentang perkawinan.

Tiga: Bab III berisi tentang peminangan. Dalam bab ini terdiri dari 3 Pasal yang membahas tentang peminangan, seperti tatacara peminangan, proses peminangan, akibat hukum peminangan, dan putusnya peminangan. Seperti Pasal 13 ayat (1) disebutkan bahwa peminangan belum menimbulkan akibat hukum dan para pihak bebas memutuskan hubungan pinangan.

Empat: Bab IV yang membahas tentang rukun dan syarat perkawinan. Pada bab IV ini berisi dibagi menjadi lima bagian, yaitu bagian kesatu membahas tentang rukun, bagian kedua calon mempelai, bagian ketiga wali nikah, bagian keempat saksi nikah, dan bagian kelima adalah akad nikah. Dalam bab ini juga berisi 16 Pasal yang berkaitan dengan syarat dan rukun nikah, yaitu calon mempelai, wali nikah, dan akad nikah.

Lima: Bab V berisi tentang mahar. Pasal 30 pada bab ini dijelaskan bahwa calon mempelai pria wajib membayar mahar kepada calon mempelai wanita yang jumlah, bentuk dan jenisnya disepakati oleh kedua belah pihak.

Enam: Bab VI berisi tentang larangan kawin. Bab ini berisi 6 Pasal yang berkaitan dengan larangan kawin baik bagi laki-laki maupun perempuan.

Tujuh: Bab VII berisi tentang perjanjian perkawinan. Pada bab ini berisi 8 Pasal yang berkaitan dengan perjanjian perkawinan. 
Delapan: Bab VIII berisi tentang kawin hamil. Dalam Pasal 53 dijelaskan bahwa seorang wanita hamil di luar nikah dapat dikawinkan dengan pria yang menghamilinya.

Sembilan: Bab IX berisi tentang beristri lebih dari satu orang. Bab ini berisi 5 Pasal yang menjelaskan tentang kebolehan beristri lebih dari satu, alasan dan tatacaranya.

Sepuluh: Bab X berisi tentang Pencegahan Perkawinan. Pada bab ini memuat 10 Pasal yang berkaitan dengan pendegahan perkawinan.

Sebelas: Bab XI berisi hak dan kewajiban suami Istri.

Duabelas: Bab XII berisi harta kekayaan dalam perkawinan.

Tigabelas: Bab XIII pemeliharaan anak,

Empatbelas: Bab XIV Perwalian.

Limabelas: Bab XV Putusnya perkawinan.

Enambelas: Bab XVI akibat putusnya perkawinan.

Tuuhbelas: Bab XVII Rujuk, dan

Delapanbelas: Bab XIII masa berkabung.

\section{PEMBAHARUAN HUKUM KELUARGA ISLAM DI INDONESIA}

Pembaharuan hukum Islam disebabkan karena adanya perubahan kondisi, situasi tempat dan waktu sebagai akibat dari faktorfaktor yang telah dikemukakan di atas. Perubahan ini adalah sejalan dengan teori qaul qadim dan qaul jadid yang dikemukakkan oleh Imam Syafi ${ }^{\mathrm{e}} \mathrm{i}$, bahwa hukum dapat juga berubah karena berubahnya dalil hukum yang diterapkan pada peristiwa tertentu dalam melaksanakan maqâsyid syari'ah.

Dengan memperhatikan uraian diatas dapat diketahui bahwa pembaharuan hukum keluarga Islam telah terjadi dalam kurun waktu yang cukup lama, berproses dengan kondisi dan situasi serta sesuai dengan tuntutan zaman. Hal ini disebabkan karena norma-norma yang terkandung dalam kitab-kitab fiqh sudah tidak mampu lagi memberi solusi terhadap masalah baru yang terjadi. Sebagai contoh dalam bidang hukum keluarga seperti perkawianan yang ijab qabulnya dilakukan melalui via telepon, pemberian harta waris kepada anak angkat dengan 
cara wasiat wajibah dan lain sebagainya. Hal ini telah mendorong negara untuk mengaturnya dalam berbagai peraturan perundang-undangan. Menurut para pakar hukum Islam di Indonesia, pembaharuan hukum Islam yang terjadi saat ini disebabkan oleh beberapa faktor, diantaranya yaitu: ${ }^{10}$

(1) Untuk mengantisipasi kekosongan hukum karena norma-norma yang terdapat dalam kitab-kitab fiqih tidak mengaturnya, sedangkan kebutuhan masyarakat terhadap hukum terkait masalah yang baru terjadi sangat mendesak untuk diterapkan;

(2) Pengaruh globalisasi dan IPTEK sehingga perlu ada aturan hukum yang mengaturnya, terutama masalah-masalah yang belum ada aturan hukumnya;

(3) Pengaruh reformasi berbagai bidang yang memberikan peluang terhadap hukum Islam untuk bahan acuan dalam membuat hukum nasional;

(4) Pengaruh pembaharuan pemikiran hukum Islam yang di laksanakan oleh para mujtahid baik tingkat internasional ataupun nasional.

Pembaharuan hukum Islam adalah upaya untuk melakukan penyelarasan pemahaman dan aplikasi ajaran Islam dibidang hukum dengan kemajuan modern dengan tetap berdasarkan pada semangat ajaran Islam. Adapun tujuan pembaharuan hukum keluarga Islam secara umum dapat pula di kelompokan sebagai tersebut, yaitu: 1) Unifikasi hukum perkawinan; 2) Peningkatan status wanita; 3) Respon terhadap perkembangan dan tuntutan zaman; 4) Memberikan kepastian hukum bagi masalah-masalah perkawinan; 5) Menjadi pegangan hakim.

\section{KESIMPULAN}

Hukum Keluarga yang ada di Indonesia tercantum dalam UU No. 1 Tahun 1974, PP. No. 9 Tahun 1975 serta Kompilasi Hukum Islam. Bentuk sebuah Negara bermacam-macam, ada negara Islam, negara muslim, dan negara sekuler. Negara Islam dan negara muslim masih ada kelonggaran bagi muslim untuk melaksanakan ritual ibadahnya dan Negara ikut memfasilitasinya, baik tentang ajaran hukumnya maupun fasilitas ibadahnya seperti masjid, dll. Dalam negara seperti model ini, muslim tidak akan menemukan kesukaran dalam mengaplikasikan hukum

10 Ali, Muhammad Daud. Hukum Islam dan Peradilan Agama. Jakarta: P.T. Raja Grafindo. 1997 
Islam dalam kesehariannya, seperti ibadah shalat, puasa, naik haji, termasuk pernikahan, dll. UUD 1945 Pasal 1 Ayat 3 menyebutkan bahwa Indonesia adalah Negara hukum. Karena itu, hukum Islam yang merupakan bagian dari sistem hukum yang berlaku di Indonesia. 


\section{DAFTAR PUSTAKA}

Anderson, J. N. D. (1994). Islamic Law in the Moderen World, diterjemabkan oleh Mabmud Husain dengan judul Hukum Islam di Dunia Modern Cet. I, Yogyakarta: Tiara Wacana Yogya.

Azizy, A. Qodri A. (2004). Hukum Nasional: Eklektisisme Hukum Islam \& Hukum Umum. Jakarta: Teraju

Bisri, Cik Hasan. Kompilasi Hukum Islam dan Peradilan Agama dalam Sistem Hukum Nasional. Jakarta: Logos. 1999.

Donohue, John. Islam dan Pembaharuan Ensiklopedi Masalab-Masalah. Jakarta: Rajawali Press. 1995.

Hanafi, Ahmad. (1989). Pengantar dan Sejarah Hukum Islam, Cet. V. Jakarta: PT. Bulan Bintang.

Hasan Khalil, Rasyad, (2009). Tarikh Tasyri', Sejarah Legislasi Hukum Islam. Jakarta: Amzah.

Hoeve, Van. (1994). Ensiklopedi Islam. Jakarta: PT. Ichtiar Baru.

Mudzhar, M. Dampak Gender Terbadap Perkembangan Hukum Islam. Jurnal Studi Islam. Volume ke-1 Nomor 1: 1999.

Muttaqien, Dadan. Peradilan Agama dan Kompilasi Hukum Islam dalam Tata Hukum Indonesia.Yogyakarta : UII Press. 1999.

Nasution, Harun. (1991). Pembaharuan dalam Islam; Sejarah Pemikiran dan Gerakan. Jakarta: Bulan Bintang.

Roibin, (2010). Penetapan Hukum Islam dalam Lintasan Sejarah, Malang: UINMaliki Press.

Saeed, Abdullah. Pemikiran Islam: Sebuah Pengantar. Yogyakarta: Baitul Hikmah. 2014.

Yatim, Badri. (1999). Sejarah Peradaban Islam. Jakarta: PT. Raja Grafindo Persada. 